\title{
Feasibility and early outcomes of laparoscopic plicated sleeve gastrectomy: a case-control study
}

\section{Technika i wstępne wyniki leczenia operacyjnego chorobliwej otyłości metoda plikowanej resekcji rękawowej żołądka - badanie kliniczno-kontrolne}

\author{
Tomasz Rogula1,2 \\ ${ }^{1}$ Department of Surgery, Case Western Reserve, University School of Medicine, Cleveland, OH, USA \\ Co-Director, Bariatric and Metabolic Surgery Center \\ ${ }^{2}$ Department of Surgery and Surgical Nursing with Research Laboratory, Institute of Medical Sciences, Faculty of Medicine \\ and Health Sciences, Jan Kochanowski University, Kielce, Poland \\ Head of the Department: Prof. Stanisław Głuszek MD, PhD
}

Key words: laparoscopic sleeve gastrectomy, gastric plication, bariatric surgery.

Słowa kluczowe: laparoskopowa rękawowa resekcja żołądka, plikacja żołądka, chirurgiczne leczenie otyłości.

\begin{abstract}
Introduction: Sleeve gastrectomy (SG) continues to gain popularity as a viable weight loss procedure with well-documented outcomes and procedure-specific adverse effects. It has become increasingly indicated for the treatment of morbid obesity. Aim of the research: To compare a novel approach to SG, which aims to reduce SG-specific complications, to the standard SG procedure.

Material and methods: Sixteen morbidly obese patients with a mean body mass index (BMI) of $48.5 \mathrm{~kg} / \mathrm{m}^{2} \pm \mathrm{SD}$ who underwent the novel laparoscopic plicated sleeve gastrectomy (LPSG) were retrospectively studied. The control group included 18 patients who underwent laparoscopic SG. Study and control groups were matched for BMI and gender. Study group patients underwent a partial SG with imbrication of the distal $2 / 3$ of the staple line with $2 \mathrm{~cm}$ overlap and $3-4 \mathrm{~cm}$ of the prepyloric stomach. Control group SG patients had their staple line oversewn without plication. Outcomes at 3, 6 and 12 months were compared and analyzed.

Results: There was no statistically significant difference in weight loss at 12 months between the LPSG and SG groups. Postoperative nausea was comparable between the two groups. No major complications were noted in either group.

Conclusions: The LPSG is a modification of the standard SG which has comparable outcomes, safety and feasibility. It may lead to a decrease in unwanted complications such as sleeve stricture or obstruction. Further studies on long-term outcomes are needed to assess its value as a bariatric procedure.
\end{abstract}

\section{Streszczenie}

Wprowadzenie: Rękawowa resekcja żołądka (sleeve gastrectomy - SG) jest często wykonywanym zabiegiem w leczeniu otyłości chorobliwej z dobrze udokumentowanymi wynikami oraz znanymi efektami ubocznymi i powikłaniami. Cel pracy: Porównanie wyników zmodyfikowanej plikowanej resekcji rękawowej ze standardowa resekcją rękawową. Materiał i metody: Szesnastu pacjentów chorobliwie otyłych, ze średnim wskaźnikiem masy ciała (body mass index - BMI) $48,5 \mathrm{~kg} / \mathrm{m}^{2}$ przeszło zabieg laparoskopowej plikowanej resekcji rękawowej żołądka (laparoscopic plicated sleeve gastrectomy - LPSG). Wyniki analizowano retrospektywnie. Grupę kontrolną stanowiło 18 pacjentów poddanych standardowej laparoskopowej SG. Badane grupy były zbieżne pod względem BMI i płci. Pacjenci z grupy badanej przeszli częściową resekcję rękawową żołądka z plikacją dystalnej 2/3 linii staplerów (plikacja $2 \mathrm{~cm}$ ) w odległości $3 \mathrm{~cm}$ od odźwiernika. U pacjentów z grupy kontrolnej linia staplerów była obszyta bez wytworzenia plikacji. Wyniki porównano po 3, 6 i 12 miesiącach od operacji.

Wyniki: Nie stwierdzono statystycznie istotnych różnic w utracie masy ciała pomiędzy badanymi grupami. Nudności wystąpiły u podobnej liczby pacjentów w obu grupach. Nie odnotowano poważnych powikłań w obu grupach.

Wnioski: Laparoskopowa plikowana resekcja rękawowa żołądka jest modyfikacją standardowej SG pozwalająca na uzyskanie podobnych wyników. Modyfikacja ta może się przyczynić do zmniejszenia ryzyka zwężeń i niedrożności żołądka. Niezbędne są dalsze badania dotyczące długotrwałych efektów, aby ocenić jej wartość jako procedury bariatrycznej. 


\section{Introduction}

The morbid obesity epidemic continues to be a daunting problem in both the developed and developing worlds. It is directly linked to the increased prevalence of comorbidities such as type II diabetes mellitus, hypertension, hyperlipidemia and cardiovascular disease, all of which continue to be of great financial strain on the worldwide healthcare system. Furthermore, morbid obesity reduces the life expectancy of men by 12 years and women by 9 years, with a great toll on the quality of life and mental health of those affected [1]. The World Health Organization (WHO) formally recognized morbid obesity as an epidemic in 1997 and by 2008, 1.5 billion adults were overweight [2].

Bariatric surgery has made formidable advances in the treatment of obesity and its associated comorbidities. It is now considered to be the most effective means for excess weight loss (EWL) [3] and is viewed by some as the most efficacious treatment for diabetes [4]. Bariatric surgery has been classified into three mechanisms of action: restrictive, malabsorptive, and combined restrictive and malabsorptive [5]. The most common procedures performed include the laparoscopic Roux-en-Y gastric bypass (LRYGB), a combined mechanism, and laparoscopic sleeve gastrectomy (LSG), laparoscopic adjustable gastric banding (LAGB) and laparoscopic gastric greater curvature plication (LGCP), which all have restrictive mechanisms.

Gastric plication was introduced as an attempt to decrease the risk of complications from LSG (mainly staple line leak) and to provide a non-stapled, reversible weight-loss solution [6]. However, gastric plication has its own set of procedure-specific side effects and complications, including postoperative nausea and vomiting, which may be related to the large stomach folds imbricated into the gastric lumen [7]. Long-term outcomes are still under investigation, but some studies have already shown partial weight regain, likely due to flattening of the imbricated gastric folds over time [8].

Laparoscopic sleeve gastrectomy continues to gain widespread acceptance, with long-term outcomes that are comparable to other bariatric approaches [5]. Despite the recent surge in popularity, LSG is not without its own procedure-specific complications. For instance, the long staple line inherent to LSG has been recognized as a potential source of disruption and leak a very difficult complication to treat [9]. Hence, some surgeons began oversewing the staple line in hopes of reducing leak rates by creating additional protective layers of tissue. The outcomes of this approach are still being evaluated, with some studies showing it to be effective in leak prevention and others demonstrating no benefit $[10,11]$. Another yet to be established controversy with LSG is sleeve size and calibration. Whereas a smaller diameter of the sleeve may impro- ve weight loss, it may also result in poor meal tolerance, nausea and frequent vomiting [12].

\section{Aim of the research}

Herein, we introduce a novel bariatric procedure: laparoscopic plicated sleeve gastrectomy (LPSG). By definition, it is a modified LSG with the remaining dorsal aspect of the stomach plicated over the sleeve. In creating and investigating a hybrid of the LSG and LGCP, we hope to ameliorate the side effects and complications inherent to LSG and LGCP: stricture, impaired gastric emptying and regurgitation related to a tight sleeve.

\section{Material and methods}

This retrospective study included patients who underwent LPSG (study group) or standard LSG (control group) at the Cleveland Clinic from January 2008 to October 2012 with at least 12 months follow-up. The inclusion criteria for all groups were age between 18 and 65 years and body mass index (BMI) greater than $35 \mathrm{~kg} / \mathrm{m}^{2}$. The exclusion criteria were previous gastric surgery, psychiatric illness and severe gastroesophageal reflux disease. The study and control groups were matched for preoperative weight, BMI, sex and age. The prospectively collected data included patient demographics, operative parameters and postoperative outcomes. Patient demographics extracted included age, sex, BMI and comorbidities. Surgical time was calculated from incision time to start of wound closure. Both intra- and postoperative complications were recorded and analyzed. All patients were assessed at 1, 3, 6 and 12 months. During follow-up visits, weight-loss and complications were recorded. Minor complications included nausea, vomiting, dietary difficulties, vitamin deficiency, seroma, wound infection and acid reflux. Major complications included mortality, dehiscence, staple line leak or narrowing, re-operation, readmission, revision, blood transfusion, and hernia. All patients met NIH criteria for bariatric surgery and underwent our institute's standard preoperative evaluation, including internal medicine, psychology and nutrition consultations. Informed consent for all procedures was obtained. Permission to perform the laparoscopic plicated sleeve gastrectomy was obtained from the Cleveland Clinic Internal Review Board.

\section{Surgical technique}

Abdominal access and port placement were similar for both LPSG and SG. We used a standard 5-trocar approach, with $5 \mathrm{~mm}$ trocars placed at the left and right subcostal areas, two $12 \mathrm{~mm}$ trocars at the right paramedial area for staplers and suturing, and one port at the umbilicus (for the laparoscope). We used $5 \mathrm{~mm}$ and $12 \mathrm{~mm}$ ENDOPATH XCEL bladeless trocars with Opti- 
view technology. The patients were placed in steep reverse Trendelenburg position, with the primary surgeon standing on the right and an assistant on the left. Access to the peritoneal cavity is achieved using $5 \mathrm{~mm}$ trocars at the left subcostal area. The short gastric vessels, gastro-splenic attachments and the omentum are taken down with a harmonic scalpel (Harmonic Ace).

Laparoscopic plicated sleeve gastrectomy starts with marking the distal point of resection. After division of the greater omentum along the greater curvature, the first green load endostapler (Echelon Flex) is applied about $5-7 \mathrm{~cm}$ proximal to the pylorus, parallel to the lesser curvature, with lateral flexion of the stapler. Attention is paid not to narrow the incisura angularis. Prior to firing the stapler, a 32 Fr gastroscope is passed down to the pre-pyloric area to prevent stricture and to calibrate the sleeve. A series of blue Endo GIA staple loads are then applied to complete the gastrectomy. Staple loads are applied without making the staple line too tight to the calibrating gastroscope, leaving at least a $2 \mathrm{~cm}$ distance between the gastroscope and the staple line both anteriorly and posteriorly. A distance of at least $5-7 \mathrm{~cm}$ is maintained at the prepyloric area, leaving it larger than the rest of the sleeve. The imbrication is done using an Endo Stitch with Surgidac 2-0 green suture. It starts at about 1-2 cm below the staple line, on the greater curvature of the pre-pyloric stomach. This area is plicated with a single layer interrupted suture, which continues over the staple line. The staple line is pushed down with a grasper and seromuscular bites are applied approximately $2 \mathrm{~cm}$ medially from the staple line on the anterior and posterior gastric wall. The imbrication is less at the upper part of the staple line to about $1 \mathrm{~cm}$ and it stops at about $2 / 3$ of the length of the stapler line. If significant bleeding from the staple line is noticed or there is any concern about staple line disruption, the remainder of the staple line is oversewn without plication (Figures 1-2).

Standard LSG consists of mobilizing the greater curvature of the stomach from the angle of His to within $1 \mathrm{~cm}$ of the pylorus using the Harmonic scalpel. A Flexible endoscope is passed down the esophagus along the lesser curvature of the stomach into the pylorus. We then apply the green load stapler parallel to the lesser curvature beginning approximately $2 \mathrm{~cm}$ from the pylorus. One or two further green loads are applied parallel to the endoscope and then multiple blue loads are applied up toward the angle of His. Staple lines are examined on both sides. We oversew the staple line from the angle of His down to the distal end with Lambert invaginating sutures. The invagination involves only the staple line and about $5 \mathrm{~mm}$ of surrounding stomach wall, without an associated plication. In both procedures, the gastric remnant is removed in a sterile bag through the right upper quadrant port site. Endoscopy with insufflation is done to assess for leaks, ble-

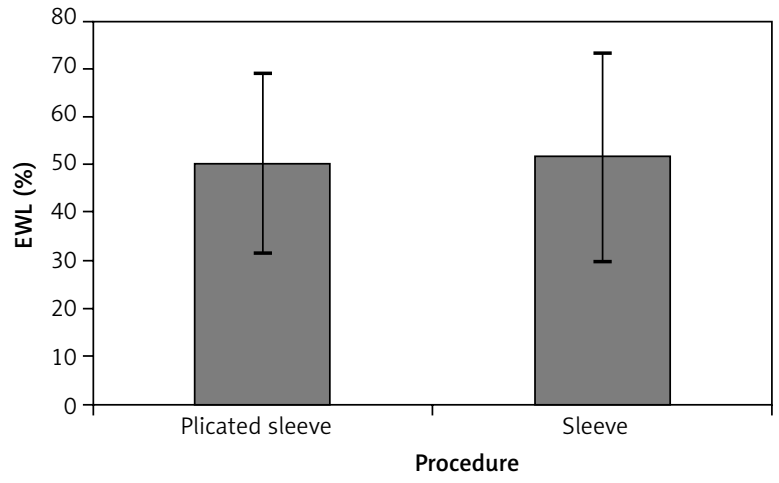

Figure 1. The EWL\% mean and standard deviation for the plicated sleeves and standard sleeve gastrectomies were $50.28 \pm 18.7$ and $51.57 \pm 21.6$ respectively. There was no statistically significant difference between plicated sleeve and sleeve when compared at 1 year with a $p$-value of 0.43

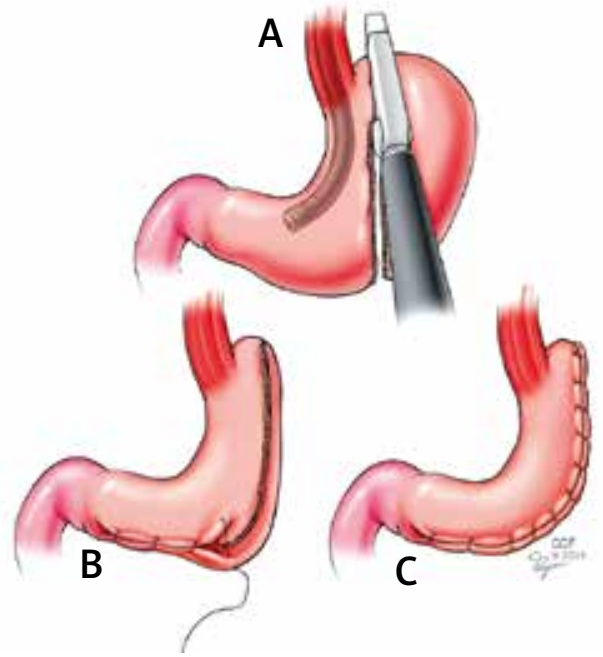

Figure 2. Technique of plicated sleeve gastrectomy: calibration of sleeve gastrectomy with a gastroscope (A) and gradual plication of the greater curvature of the stomach $(B, C)$

eding, or obstruction. Of note, all SG cases were done by 1 of 3 experienced bariatric surgeons (TR, SB, PS); LPSG was done by one surgeon (TR).

\section{Statistical analysis}

Statistical analysis was carried out using JMP Pro, Version 9. SAS Institute Inc., Cary, NC, 1989-2013.

\section{Results}

A total of 34 patients were included in the study (16 LPSG and 18 LSG). The average preoperative BMI values for the LPSG and LSG groups were 48.5 
Table 1. Demographics of study participants. The average age, average body mass index (BMI), and gender of participants in the plicated sleeve and sleeve gastrectomy group are presented

\begin{tabular}{|c|c|c|}
\hline Procedure & Age & Value of $p$ \\
\hline Plicated sleeve $(n=16)$ & $52 \pm 2.53$ & \multirow[t]{2}{*}{$\leq 0.01^{\star}$} \\
\hline Gastric sleeve $(n=18)$ & $45 \pm 1.96$ & \\
\hline \multicolumn{3}{|c|}{ Gender (F) } \\
\hline Plicated sleeve & $9(60 \%)$ & \multirow[t]{2}{*}{$0.15^{\star \star}$} \\
\hline Gastric sleeve & $13(72 \%)$ & \\
\hline \multicolumn{3}{|c|}{ Initial BMI } \\
\hline Plicated sleeve & $48.50 \pm 12.9$ & \multirow[t]{2}{*}{$0.43^{\star}$} \\
\hline Gastric sleeve & $48.98 \pm 11.8$ & \\
\hline
\end{tabular}

${ }^{\star}$ One way ANOVA, ${ }^{*}$ C2 2 - Pearson's correction.

Table 2. Operative time, \% of EWL at 1 year and incidence of nausea and vomiting of participants in the plicated sleeve and standard sleeve gastrectomy are presented

\begin{tabular}{|l|c|c|}
\hline Procedure & Operative time [min] & Value of $p$ \\
Plicated sleeve $(n=16)$ & $98 \pm 26$ & $0.16^{*}$ \\
\hline Gastric sleeve $(n=18)$ & $109 \pm 33$ & $0.43^{*}$ \\
Plicated sleeve & EWL\% at 1 year & $>0.05^{* *}$ \\
\hline Gastric sleeve & $50.28 \pm 18.7$ & \\
Plicated sleeve & $51.57 \pm 21.6$ & $>05^{* *}$ \\
\hline Gastric sleeve & Nausea: yes $n(\%)$ & \\
Plicated sleeve & $2(13)$ & \\
\hline Gastric sleeve & Emesis: yes $n(\%)$ & \\
\hline
\end{tabular}

${ }^{*}$ One way ANOVA, ${ }^{*} \chi^{2}-$ Pearson's correction.

$\pm 12.9 \mathrm{~kg} / \mathrm{m}^{2}$ and $48.9 \pm 11.8 \mathrm{~kg} / \mathrm{m}^{2}$, respectively, and the average ages were $52 \pm 3$ years and $45 \pm 2$ years, respectively. The remaining patient demographics are summarized in Table 1 . Relevant comorbidities included hypertension in 26 (57\%) subjects, diabetes mellitus in 14 (30\%), hyperlipidemia in 13 (28\%), obstructive sleep apnea in 11 (24\%), fatty liver disease in $7(15 \%)$, mild gastroesophageal reflux disease in $5(11 \%)$, chronic obstructive lung disease in $2(4 \%)$, and end stage renal disease in $1(2 \%)$. Patients were matched for BMI and sex from our prospective database of all bariatric procedures between 2008 and 2012 at the Cleveland Clinic, Cleveland, Ohio. The present series indicates a comparable EWL at 1-year follow-up between the LPSG and LSG groups. The mean EWL \pm standard deviation for the LPSG and LSG groups was $50.28 \pm 18.7$ and $51.57 \pm 21.6$, respectively ( $p=$ $0.43)$. The mean operative time was $98 \pm 26 \mathrm{~min}$ for LPSG and $109 \pm 33 \mathrm{~min}$ for SG $(p=0.16)$. None of the
LPSG patients vomited postoperatively, while 1 LSG patient had at least one emesis episode $(p>0.05)$. Other minor complications included nausea (13\% of LPSG and 22\% of LSG; $p>0.05$ ), 1 patient with minimal weight loss, one with vitamin deficiency, one with subjective heartburn, and one with difficulty in advancement of diet (resolved fully at follow-up). There were no major complications in either group.

\section{Discussion}

Restrictive bariatric surgery has recently gained popularity, mainly because it avoids the malabsorptive side effects of intestinal bypass and the complications that surround anastomotic leak. However, LSG can result in staple line disruption or leak, a situation which is very difficult to manage [13-15]. Another feared complication of LSG is sleeve stricture, a serious complication that often needs revisional intervention [13-15]. 
The size of the gastric sleeve remains a debatable issue, with some authors recommending a gastric tube less than $40 \mathrm{Fr}$ [12]. Whereas resection of the fundus and gastric body has been commonly adapted, the size of the pre-pyloric area varies depending on the surgeon. Some authors report improved outcomes by creating a very tight sleeve after complete resection of the greater curvature all the way down to the pylorus. This technique may result in impaired stomach emptying and significant regurgitation of gastric contents [16].

Creating a total sleeve can be technically challenging, especially at the incisura angularis, where the staple line turns and may result in narrowing or kinking of the gastric sleeve; this decrease in luminal diameter can also lead to impaired emptying and regurgitation. Theoretically, leaving this part of the stomach intact could prevent this phenomenon, but it is unclear if it would compromise weight loss [7].

Over-sewing and buttresing the staple line with the intention of reducing the staple line leak remains controversial. Some studies suggested no impact on risk of leakage after over-sewing [10, 11].

Greater curvature plication was introduced as an attempt to avoid staple line disruption and to minimize the amount of foreign bodies (staples) left in situ. Furthermore, it was invented as a potentially reversible procedure that could be less expensive than LSG. Although it appears to be safe, with less frequent severe complications, gastric plication has its own set of problems, mainly postoperative nausea/vomiting and poor long-term weight loss. Recurrent emesis is postulated to be due to the large plicated stomach folds occupying the proximal gastric lumen; poor weight-loss is likely related to flattening of the gastric folds over time $[6,8]$.

In the present study, we present initial comparative outcomes of a novel hybrid procedure which combines key elements of both LSG and LGCP. By leaving the distal stomach unstapled, we aim to avoid permanent narrowing of the antrum or incisura angularis by ensuring a straight staple line. To maintain the desired lumen and meal size, we plicate the pre-pyloric stomach under endoscopic control. Stitches may be removed and placed at a further distance, which allows for appropriate calibration, even after surgery. The larger/adjustable volume of the distal stomach theoretically should decrease back-pressure on the proximal staple line, thus decreasing the chance of staple line disruption and leakage $[17,18]$. Furthermore, we postulate that gastric emptying may be improved in plicated sleeves, which should hopefully decrease postoperative nausea, vomiting and regurgitation. By resecting the proximal part of the stomach, including the body and the fundus, we aim to avoid the typical LGCP side effects of nausea/vomiting, fundus prolapse, and intra-fold abscess from small gastric wall perforations caused by stitches.
As shown in our 12-month follow-up, the weight loss achieved in the LPSG group was at least as good as the LSG group. A mean EWL of $50.3 \pm 18.7 \%$ and $51.6 \pm 21.6 \%$ was achieved for LPSG and SG, respectively. This is likely to be due to resecting the fundus and thus avoiding expansion of this part of the stomach, which may lead to weight regain. We acknowledge that other studies have shown a 12-month EWL of $60-65 \%$ [3] for LGCP, and thus continued investigation of our novel procedure will be required to ascertain its true efficacy. There was no significant difference in surgical time between the two procedures.

This study does have limitations including retrospective design, small patient numbers and a relatively short follow-up period; the long-term efficacy of our LPSG requires continued evaluation. Another limitation worth noting is that 1-year follow-up was performed over the phone for $13(38 \%)$ patients. The LPSG procedures were performed by only one surgeon, compared to 3 different surgeons for LSG, and this is another potential limitation. Furthermore, despite an attempt to standardize our LSG and LPSG approaches, some differences in surgical technique may have occurred between the various surgeons. Three patients initially assigned to the study group had to be removed due to steroid therapy for an unrelated condition which resulted in significant weight regain or the need for a second stage procedure (gastric bypass) prior to 1-year follow-up (2 patients). Lastly, measurement of the gastric volume was estimated subjectively based on endoscopic evaluation. Further prospective studies of longer duration are needed to properly assess the utility of this novel procedure.

\section{Conclusions}

Based on our experience, laparoscopic plicated sleeve gastrectomy is safe and feasible with no increase in operative time compared to sleeve gastrectomy. It combines features of sleeve gastrectomy and gastric plication with very similar weight-loss efficacy to sleeve gastrectomy and less postoperative nausea and vomiting. The volume of the unresected antrum may be easily adjusted by reversible plication of the greater curvature.

\section{Conflict of interest}

The authors declare no conflict of interest.

\section{References}

1. Buchwald H. Consensus conference statement - Bariatric surgery for morbid obesity: health implications for patients, health professionals, and third-party payers. Surg Obes Rel Dis 2005; 1: 371-81.

2. World Health Organization. http://www.who.int/mediacentre/factsheets/fs311/en/index.html 
3. Kourkoulos M, Giorgakis E, Kokkinos C, et al. Laparoscopic gastric plication for the treatment of morbid obesity: a review. Minim Invasive Surg 2012; 2012: 696348.

4. Schauer PR, Kashyap SR, Wolski K, et al. Bariatric surgery versus intensive medical therapy in obese patients with diabetes. N Engl J Med 2012; 366: 1567-76.

5. Franco JV, Ruiz PA, Palermo M, Gagner M. A review of studies comparing three laparoscopic procedures in bariatric surgery: sleeve gastrectomy, Roux- en-Y gastric bypass, and adjustable gastric banding. Obes Surg 2011; 21: 1458-68.

6. Talebpour M, Amoli BS. Laparoscopic total gastric vertical plication in morbid obesity. J Laparoendosc Adv Surg Tech 2007; 17: 793-8.

7. Skrekas G, Antiochos K, Stafyla VK. Laparoscopic gastric greater curvature plication: results and complications in a series of 135 patients. Obes Surg 2011; 21: 1657-63.

8. Talebpour M, Motamedi SMK, Talebpour A, Vahidi H. Twelve year experience of laparoscopic gastric plication in morbid obesity: development of the technique and patient outcomes. Ann Surg Innovat Res 2012; 6: 7.

9. Breton JO, Naranjo SP, Laborda SG, et al. Effectiveness and complications of bariatric surgery in the treatment of morbid obesity. Nutr Hosp 2005; 20: 409-14.

10. Knapps J, Ghanem M, Clements J, Merchant AM. A systematic review of staple-line reinforcement in laparoscopic sleeve gastrectomy. JSLS 2013; 17: 390-9.

11. Aggarwal S, Sharma AP, Ramaswamy N. Outcome of laparoscopic sleeve gastrectomy with and without staple line oversewing in morbidly obese patients: a randomized study. J Laparoendosc Adv Surg Tech A 2013; 23: 895-9.

12. Atkins ER, Preen DB, Jarman C, Cohen LD. Improved obesity reduction and comorbidity resolution in patients treated with 40 -French bougie versus 50 -French bougie four years after laparoscopic sleeve gastrectomy: analysis of 294 patients. Obes Surg 2012; 22: 97-104.

13. Deitel M, Gagner M, Erickson AL, Crosby RD. Third international summit: current status of sleeve gastrectomy. Surg Obes Relat Dis 2012; 7: 749-59.

14. Gagner M, Deitel M, Kalberer TL, et al. The second international consensus summit for sleeve gastrectomy, March 19-21, 2009. Surg Obes Relat Dis 2009; 5: 476-85.

15. Deitel M, Crosby RD, Gagner M. The first international consensus summit for sleeve gastrectomy (SG), New York City, October 25-27, 2007. Obes Surg 2008; 18: 487-96.

16.Papailou J, Albanopoulos K, Toutouzas KG, et al. Morbid obesity and sleeve gastrectomy: how does it work? Obes Surg 2010; 20: 1448-55.

17. Aurora AR, Khaitan L, Saber AA. Sleeve gastrectomy and the risk of leak: a systematic analysis of 4,888 patients. Surg Endosc 2012; 26: 1509-15.

18. Burgos AM, Braghetto I, Csendes A, et al. Gastric leak after laparoscopic sleeve gastrectomy for obesity. Obes Surg 2009; 19: 1672-7.

\section{Address for correspondence:}

Tomasz Rogula MD, PhD

Department of Surgery

Case Western Reserve

University School of Medicine

2109 Adelbert Rd

44106 Cleveland, $\mathrm{OH}$, USA

Phone: +1 2162969053

E-mail: tomrogula@gmail.com 